\title{
Enzymatical hydrolysis of proteins from Tra fish flesh scrap
}

\author{
Thien T. Le*, Thuy T. Bui, \& Ngan N. T. Trinh
}

Faculty of Food Science and Technology, Nong Lam University, Ho Chi Minh City, Vietnam

\author{
ARTICLE INFO \\ Research paper \\ Received: October 23, 2017 \\ Revised: October 30, 2017 \\ Accepted: November 02, 2017 \\ Keywords \\ Alcalase \\ Enzymes \\ Hydrolysis \\ Tra catfish

\section{${ }^{*}$ Corresponding author} \\ Le Trung Thien \\ Email: le.trungthien@hcmuaf.edu.vn
}

\begin{abstract}
The study was carried out to compare types of enzymes and to evaluate effects of conditions for hydrolysis of Tra fish flesh scraps. Among the four experimented enzymes including protamex, papain, neutrase, and alcalase, the last one was the most efficient in term of protein recovery yield and hydrolysis degree. The hydrolysis efficiency was at the maximum at conditions of $\mathrm{pH} 8.0$, the temperature $55^{\circ} \mathrm{C}$ and the rate of enzyme/material $1.0 \%$. At these conditions, the protein recovery yield was over $70 \%$, and hydrolysis degree was over $18 \%$. The results of the research provide a background to apply enzymes to convert Tra fish flesh scraps into a protein hydrolysate to be used as a functional ingredient or to be used in functional foods.
\end{abstract}

Cited as: Le, T. T., Bui, T. T., \& Trinh, N. T. N. (2018). Enzymatical hydrolysis of proteins from Tra fish flesh scrap. The Journal of Agriculture and Development 17(4), 112-117. 


\title{
Nghiên cứu thủy phân thịt vụn cá tra
}

\author{
Lê Trung Thiên*, Bùi Thanh Thùy \& Trịnh Ngọc Thảo Ngân
}

Khoa Công Nghệ Thực Phẩm, Trường Đại Học Nông Lâm TP. Hồ Chí Minh, TP. Hồ Chí Minh

\section{THÔNG TIN BÀI BÁO}

Bài báo khoa học

Ngày nhận: 23/10/2017

Ngày chỉnh sửa: $30 / 10 / 2017$

Ngày chấp nhận: 02/11/2017

\section{Từ khóa}

\section{Alcalase}

Cá tra

Enzyme

Thủy phân

\section{*Tác giả liên hệ}

Lê Trung Thiên

Email: le.trungthien@hcmuaf.edu.vn

\section{TÓM TẮT}

Nghiên cứu này thực hiện nhằm so sánh ảnh hưởng của loại, tỷ lệ và điều kiện thủy phân enzyme đến hiệu quả thủy phân thịt vụn cá tra. Trong vòng bốn enzyme thí nghiệm là protamex, papain, neutrase, và alcalase thì alcalase cho hiệu suất thu hồi protein và độ thủy phân cao nhất. Enzyme alcalase cho hiệu quả thủy phân cực đại trong điều kiện $\mathrm{pH} 8,0$; nhiệt độ thủy phân $55^{\circ} \mathrm{C}$ và tỷ lệ enzyme/nguyên liệu là $1,0 \%(\mathrm{w} / \mathrm{w})$, cụ thể hiệu suất thu hồi protein hơn $70 \%(\mathrm{w} / \mathrm{w})$ và độ thủy phân hơn $18 \%$ (w/w). Nghiên cứu thành công với mục tiêu đề ra và kết quả có khả năng ứng dụng vào thực tế sản xuất dịch thủy phân thịt vụn cá tra để làm nguyên liệu cải thiện tính chất công nghệ thực phẩm hay nguyên liệu chế biến thực phẩm chức năng.

\section{1. Đặt Vấn Đề}

Hiện nay, sản phẩm cá tra của Việt Nam đã có mặt trên 150 quốc gia và vùng lãnh thổ trên thế giới. Theo báo cáo của Tổng cục Thủy sản năm 2015, ước tính diện tích cá tra cả nước khoảng 5.000 ha, sản lượng 1,22 triệu tấn chiếm hơn $18 \%$ tổng sản lượng thủy sản, xuất khẩu đạt 1,6 tỷ USD chiếm hơn $23 \%$ kim ngạch xuất khẩu thủy sản cả nước. Như vậy, ngành cá tra không ngừng phát triển dẫn đến một lượng phụ phẩm rất lớn được tạo ra, trong đó thịt vụn chiếm khoảng 14\% tổng khối lượng cá sống (Do \& Truong, 2013). Bên cạnh đó, nguồn thịt vụn có giá trị dinh dưỡng tương đương thịt phi lê với hàm lượng protein khoảng $17 \%$. Có thể tận dụng nguồn protein này cho nhiều ứng dụng trong công nghệ thực phẩm, gia tăng nguồn thu nhập cho người sản xuất, giảm thiểu lãng phí, tăng hiệu suất thu hồi chất dinh dưỡng.

Chế biến sản phẩm thủy phân protein là hướng xử lý mới đang được quan tâm. Thủy phân protein thành dịch thủy phân làm tăng lên tính chất công nghệ cũng như tăng lên giá trị sinh học (tăng độ hấp thụ, hoạt tính kháng oxi hóa) của nguyên liệu. Tuy nhiên, hướng nghiên cứu này trên cá Tra vẫn còn hạn chế, đặc biệt trên đối tượng thịt vụn. Nghiên cứu này được thực hiện nhằm so sánh khả năng thủy phân protein thịt vụn cá tra của các proteases thương mại có mặt trên thị trường từ đó chọn được enzyme phù hợp và thông qua một số thí nghiệm để tìm điều kiện thủy phân phù hợp cho enzyme lựa chọn.

\section{Vật Liệu và Phương Pháp Nghiên Cứu}

\subsection{Nguyên vật liệu}

Thịt vụn cá tra thu mua tại công ty TNHH MTV Thủy Sản Mỹ Sa, Khu Công nghiệp Sa Đéc - Đồng Tháp. Nguyên liệu được xử lý sơ bộ, xay nhỏ, chứa trong bao $\mathrm{PA}$ và được trữ đông trong tủ đông ở $-20^{\circ} \mathrm{C}$ cho tới khi sử dụng. Enzyme Alcalase 2,4L EG (Novozymes - Đan Mạch) được mua tại công ty TNHH thương mại nông sản và hóa chất Phương Trâm, neutrase $\mathrm{PL}$, papain và protamex được mua tại Công ty TNHH Đầu Tư và Phát Triển Thị Trường Hóa Chất. 
Sơ đồ quy trình thí nghiệm thủy phân protein từ thịt vụn cá tra bằng phương pháp enzyme được đề xuất dựa trên nghiên cứu của Nicharee \& Sasithorn (2015) thể hiện trong Hình 1.

Thực hiện rã đông chậm nguyên liệu bằng nước. Nguyên liệu được trộn với nước cất theo tỷ lệ nước : nguyên liệu là $1: 1(\mathrm{w} / \mathrm{w})$, xử lý nhiệt mẫu dịch cá ở nhiệt độ $90^{\circ} \mathrm{C}$ trong 15 phút để bất hoạt enzyme nội tại. Sử dụng máy đồng hóa đồng nhất mẫu dịch cá trong 4 phút ở tốc độ 9.000 vòng/phút. Hỗn hợp dịch cá được hiểu chỉnh pH bằng dung dịch $\mathrm{NaOH} 1 \mathrm{~N}$ và $\mathrm{HCl} 1 \mathrm{~N}$ sao cho phù hợp với kế hoạch thực nghiệm. Quá trình thủy phân được tiến hành trong becher và phản ứng được thực hiện trong bể điều nhiệt có cánh khuấy với tốc độ 150 vòng/phút. Hỗn hợp được xử lý nhiệt đến nhiệt độ phù hợp trước khi thêm enzyme. Thời gian thủy phân cố định 6 giờ, nhiệt độ thủy phân và hàm lượng enzyme được điều chỉnh theo kế hoạch thực nghiệm. Sau thủy phân, xử lý nhiệt dung dịch mẫu ở nhiệt độ $80^{\circ} \mathrm{C}$ trong 20 phút để bất hoạt enzyme. Sau đó, thực hiện ly tâm tách béo và bã với chế độ ly tâm 5.000 vòng/phút trong 15 phút. Dịch chiết được lọc bằng giấy lọc whatman 101 phi 90 nhằm loại bỏ những cặn nguyên liệu còn sót (bã) và một phần chất béo trước khi đem phân tích các chỉ tiêu.

Điều kiện thủy phân để so sánh các enzyme được liệt kê trong Bảng 1 (dựa trên đề xuất của nhà cung cấp).

Bảng 1. Điều kiện thủy phân tối ưu của các enzyme

\begin{tabular}{cccc}
\hline Enzyme & $\mathrm{pH}$ & $\begin{array}{c}\text { Nhiệt độ } \\
\left({ }^{0} \mathrm{C}\right)\end{array}$ & $\begin{array}{c}\text { Nồng độ enzyme } \\
(\%)\end{array}$ \\
\hline Protamex & 6,5 & 55 & $0,5 \mathrm{E} / \mathrm{NL}$ \\
Alcalase & 8,0 & 55 & $0,5 \mathrm{E} / \mathrm{NL}$ \\
Papain & 7,5 & 55 & $4^{*} 10^{-4} \mathrm{E} / \mathrm{S}$ \\
Neutrase & 6,5 & 50 & $7^{*} 10^{-4} \mathrm{E} / \mathrm{S}$ \\
\hline
\end{tabular}

\subsection{Các phương pháp phân tích}

Hàm lượng ẩm được xác định bằng máy đo ẩm độ hồng ngoại. Hàm lượng đạm tổng số xác định theo phương pháp Kjeldahl (AOCS, 2008). Phân tích mức độ thủy phân protein bằng phương pháp formol được mô tả bởi Ronald \& ctv., 2005.

Hiệu xuất thu hồi protein sau quá trình thủy phân được tính toán như sau:

Hiệu suất thu hồi protein $=\frac{\mathrm{a} \times \mathrm{m}_{\mathrm{dtp}}}{\mathrm{b} \times \mathrm{m}_{\mathrm{nl}}} \times$ 100(\%), trong đó:

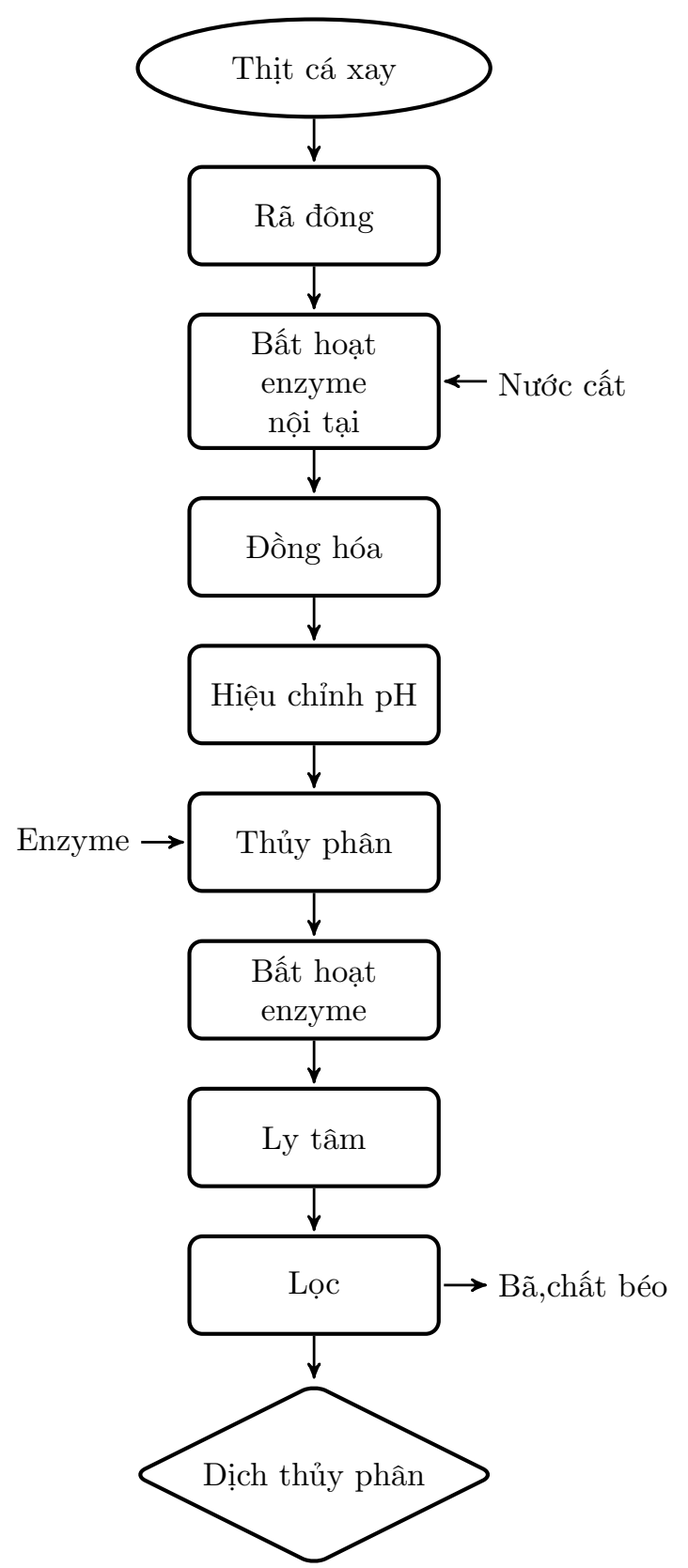

Hình 1. Sơ đồ quy trình thủy phân thịt vụn cá tra bằng enzyme. 


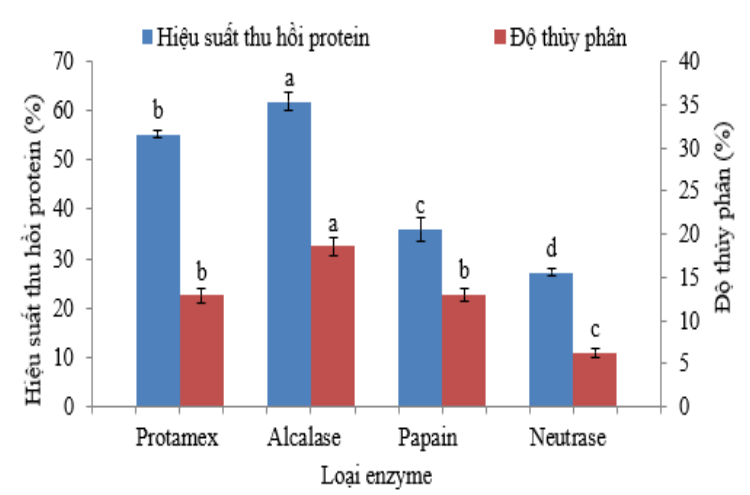

Hình 2. Ảnh hưởng loại enzyme đến hiệu suất thu hồi protein và độ thủy phân. (\%)

a: hàm lượng protein có trong dịch thủy phân

$\mathrm{m}_{\mathrm{dtp}}$ : khối lượng dịch thủy phân (g)

$\mathrm{b}$ : hàm lượng protein có trong nguyên liệu (\%) $\mathrm{m}_{\mathrm{nl}}$ : khối lượng nguyên liệu (g)

Đánh giá mức độ thủy phân thông qua khối lượng phân tử peptide trong dịch thủy phân thu được bằng kỹ thuật điện di gel sodium dodecyl sulfate - polyacrylamide (SDS-PAGE) theo phương pháp Laemmli (1970).

\subsection{Phương pháp xử lý kết quả}

Các thí nghiệm được bố trí hoàn toàn ngẫu nhiên lặp lại 3 lần. Các phân tích được lặp lại tối thiểu là hai lần và lấy giá trị trung bình. Giá trị tối ưu từ thí nghiệm trước là thông số cố định cho thí nghiệm tiếp theo. Các số liệu thu thập được xử lý thống kê bằng phần mềm: Excel 2010 và JMP 10.0 ở độ tin cậy $95 \%$.

\section{Kết Quả và Thảo Luận}

\section{1. Ảnh hưởng của loại enzyme đến hiệu quả thủy phân protein thịt vụn cá tra}

Thực hiện khảo sát nhiều loại enzyme protease khác nhau để xác định enzyme phản ứng thủy phân tốt nhất đối với cơ chất là protein thịt vụn cá tra. Kết quả được trình bày ở Hình 2 .

Kết quả cho thấy, loại enzyme ảnh hưởng có ý nghĩa đến hiệu suất thu hồi protein và độ thủy phân. Enzyme alcalase cho hiệu suất thu hồi protein và độ thủy phân cao nhất (61,90 và 18,55\% $(\mathrm{w} / \mathrm{w}))$. Nguyên nhân có thể do enzyme này có

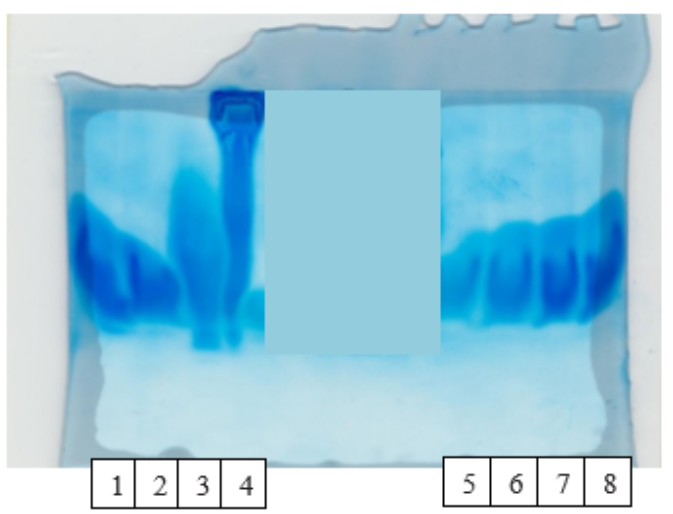

Hình 3. Hình ảnh điện di mẫu dịch thủy phân của các enzyme khác nhau ( 1 - thủy phân với protamex, 2 - alcalase, 3 - papain và 4 - neutrase) và thủy phân với alcalase ở các nhiệt độ khác nhau $\left(5-50^{\circ} \mathrm{C}, 6-\right.$ $55^{0} \mathrm{C}, 7-60^{\circ} \mathrm{C}$ và $\left.8-65^{\circ} \mathrm{C}\right)$.

hoạt tính mạnh và phù hợp với cơ chất là protein thịt vụn cá tra nên phân cắt lượng lớn liên kết peptide và phân cắt sâu hơn để tạo acid amin. Neutrase cho kết quả hiệu suất thu hồi protein và độ thủy phân thấp nhất $(27,22$ và $6,27 \%(\mathrm{w} / \mathrm{w}))$. Nguyên nhân có thể do neutrase có hoạt tính kém chỉ cắt protein ở mức độ vừa phải hoặc tạo thành các đoạn peptide (Luan \& ctv., 2009).

Hình 3 cho thấy enzyme neutrase có độ thủy phân thấp nhất nên phân cắt các peptide yếu hơn do đó sản phẩm thủy phân có chứa các peptide có khối lượng phân tử lớn, tiếp theo là các peptide của dịch thủy phân bằng papain, protamex và dịch thủy phân bằng alcalase chứa các peptide có khối lượng phân tử nhỏ nhất. Như vậy, độ thủy phân càng cao số lượng các peptide phân tử thấp càng nhiều.

Nghiên cứu của Pham \& Tran (2013) trên phụ phẩm cá tra cũng cho thấy alcalase có hiệu quả thủy phân tốt hơn các enzyme còn lại. Vì vậy, enzyme alcalase được chọn làm giá trị cố định cho thí nghiệm tiếp theo.

\section{2. Ảnh hưởng của $\mathrm{pH}$ đến hiệu quả thủy phân protein thịt vụn cá tra}

Tiến hành khảo sát các giá trị pH khác nhau để lựa chọn $\mathrm{pH}$ thích hợp cho quá trình thủy phân thịt vụn cá tra, kêt quả theo dõi hiệu suất thu hồi protein và độ thủy phân được trình bày trong Hình 4 cho thấy, pH ảnh hưởng có ý nghĩa đến hiệu suất thu hồi protein và độ thủy phân. Khi tăng pH môi trường lên 8,0 enzyme có hiệu suất 
thu hồi protein và mức độ thủy phân đạt cực đại (71,53 và $18,30 \%)$. Nguyên nhân có thể do tại giá trị pH 8,0 trạng thái ion hóa phân tử enzyme và cơ chất thích hợp với khả năng xúc tác dẫn đến enzyme và cơ chất kết hợp với nhau dễ dàng (Pham \& Phan, 2006). Lúc này, enzyme có hoạt tính cao nhất nên phân cắt được lượng lớn các liên kết peptide tạo peptide và acid amin từ đó gia tăng khả năng thu hồi protein và độ thủy phân.

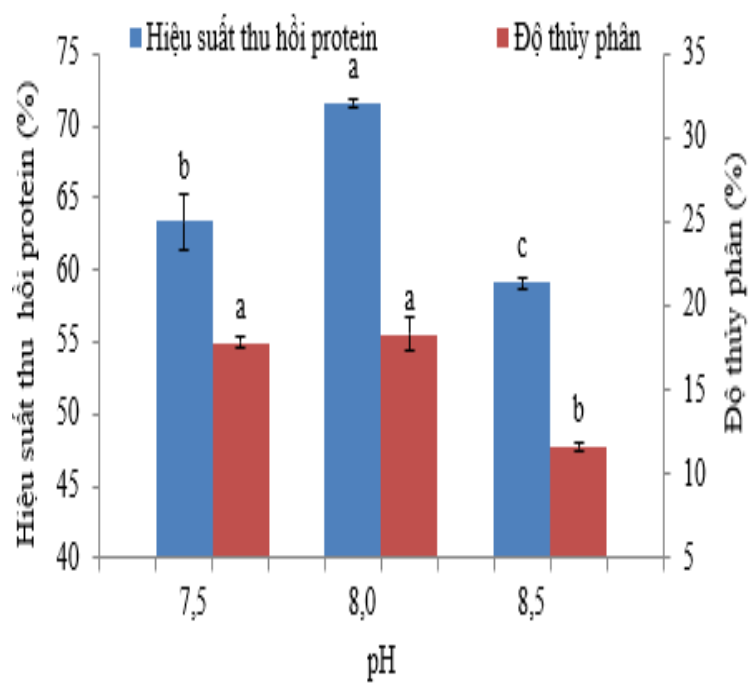

Hình 4. Ảnh hưởng của $\mathrm{pH}$ đến hiệu suất thu hồi protein và độ thủy phân.

Khi tăng $\mathrm{pH}$ đến 8,5 hiệu quả thủy phân giảm rõ rệt. Điều này có thể do giá trị $\mathrm{pH} 8,5$ nằm ngoài vùng $\mathrm{pH}$ tối thích $(7,0-8,0)$ của enzyme alcalase, ở pH quá cao hoặc quá thấp protein bị biến tính dẫn đến enzyme cũng bị mất hoạt tính (Nguyen, 1998).

\section{3. Ảnh hưởng của nhiệt độ đến hiệu quả thủy phân protein thịt vụn cá tra}

Hình 5 cho thấy, nhiệt độ ảnh hưởng có ý nghĩa đến hiệu suất thu hồi protein. Khi nhiệt độ tăng đến $55^{\circ} \mathrm{C}$ thì hiệu suất thu hồi protein đạt cực đại $(70,82 \%(\mathrm{w} / \mathrm{w}))$. Tiếp tục tăng nhiệt độ lên 60 và $65^{\circ} \mathrm{C}$ hiệu suất thu hồi không tăng và có xu hướng giảm. Độ thủy phân giữa các nghiệm thức chênh lệch không đáng kể trong khoảng 18 - 19\%, kết quả điện di (Hình 3) cũng cho thấy không có sự khác nhau rõ rệt giữa các giếng $5 ; 6 ; 7$ và 8 $\left(50 ; 55 ; 60\right.$ và $\left.65^{0} \mathrm{C}\right)$ hay độ thủy phân của bốn nghiệm thức gần như tương đương với nhau.
Kết quả này phù hợp nghiên cứu trên thịt cá sấu của Huynh (2016) với nhiệt độ $55^{0} \mathrm{C}$ là điều kiện thích hợp cho enzyme alcalase hoạt động. Như vậy, nghiệm thức nhiệt độ $55^{0} \mathrm{C}$ được chọn làm giá trị cố định cho thí nghiệm kế tiếp.

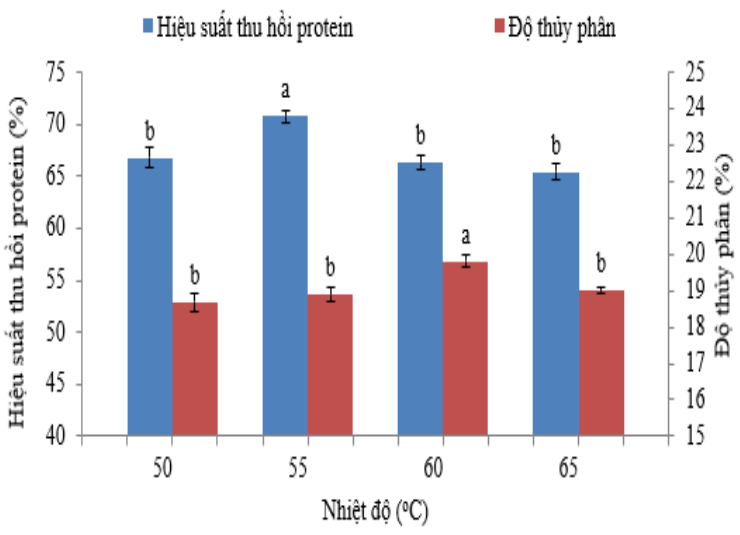

Hình 5. Ảnh hưởng của nhiệt độ đến hiệu suất thu hồi protein và độ thủy phân.

\section{4. Ảnh hưởng của tỷ lệ enzyme/nguyên liệu đến hiệu quả thủy phân protein thịt vụn cá tra}

Nồng độ cơ chất và nồng độ enzyme ảnh hưởng trực tiếp đến vận tốc phản ứng. Theo dõi hiệu suất thu hồi protein sau quá trình thủy phân và độ thủy phân để chọn ra tỷ lệ enzyme/nguyên liệu phù hợp cho quá trình thủy phân protein thịt vụn cá tra. Mẫu dịch thủy phân sau khi phân tích các chỉ tiêu được trình bày ở Hình 6 .

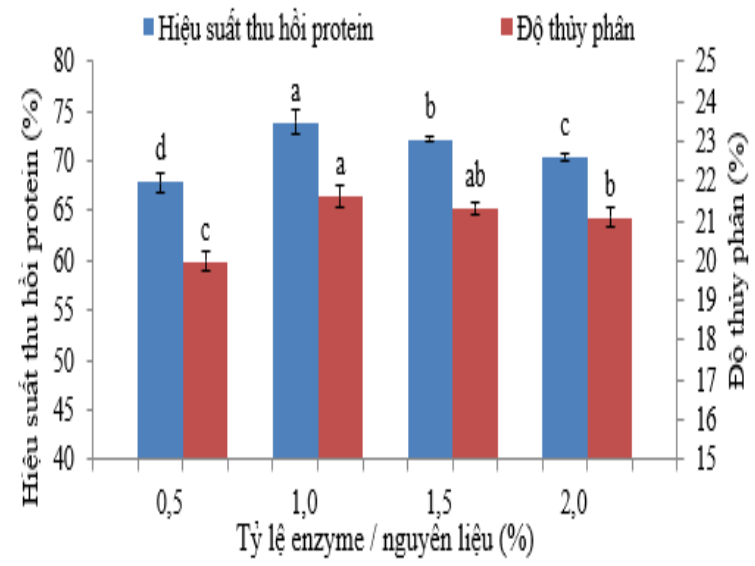

Hình 6. Ảnh hưởng của tỷ lệ enzyme/nguyên liệu đến hiệu suất thu hồi protein và độ thủy phân. 
Hình 6 cho thấy, tỷ lệ enzyme/nguyên liệu ảnh hưởng có ý nghĩa đến hiệu suất thu hồi protein và độ thủy phân. Nghiệm thức tỷ lệ enzyme/nguyên liệu $1,0 \%(\mathrm{w} / \mathrm{w})$ cho hiệu suất thu hồi protein và độ thủy phân đạt cực đại $(73,94$ và $21,61 \%$ $(\mathrm{w} / \mathrm{w}))$. Tiếp tục tăng tỷ lệ enzyme/nguyên liệu lên 1,5 và $2,0 \%(\mathrm{w} / \mathrm{w})$, hiệu suất thu hồi protein và độ thủy phân đều giảm.

Điều này phù hợp với lý thuyết, khi tăng tỷ lệ enzyme đồng nghĩa với việc tăng nồng độ enzyme, khi đó khả năng tiếp xúc giữa enzyme và cơ chất tăng, nên tốc độ phản ứng tăng cường, làm tăng hiệu quả thủy phân protein (Pham \& Phan, 2006). Tốc độ phản ứng đạt cao nhất với tỷ lệ enzyme/nguyên liệu thích hợp là 1,0\%. Tuy nhiên, nếu tỷ lệ enzyme quá cao, tốc độ phản ứng sẽ chậm lại. Nguyên nhân có thể do bản chất của enzyme là protein, những enzyme chưa tiếp xúc được với cơ chất lại có xu hướng thủy phân enzyme khác khi tỷ lệ enzyme bổ sung vào nguyên liệu quá cao.

\section{Kết Luận}

Thủy phân protein thịt vụn cá tra bằng enzyme alcalase cho hiệu hiệu suất thu hồi protein và độ thủy phân cao nhất so với enzyme protamex, papain và neutrase. Điều kiện thích hợp thủy phân thịt vụn cá tra khi sử dụng enzyme alcalase là: $\mathrm{pH}$ và nhiệt độ cho quá trình thủy phân lần lượt là 8,0 và $55^{\circ} \mathrm{C}$, tỷ lệ enzyme/nguyên liệu là $1,0 \%$ $(\mathrm{w} / \mathrm{w})$. Tại điều kiện này, hiệu suất thu hồi protein thu được là hơn $70 \%$ (w/w) và độ thủy phân hơn $18 \%(\mathrm{w} / \mathrm{w})$.

\section{Lời Cảm Ơn}

Nghiên cứu này được hỗ trợ kinh phí bởi dự án SUPA, tài trợ bởi Cồng đồng Châu Âu. Dự án quản lý bởi VASEP và Trung Tâm Sản xuất Sạch hơn Đại học Bách Khoa Hà Nội.

\section{Tài Liệu Tham Khảo (References)}

AOCS. (2008). Official methods and recommended practices of the AOCS. In Firestone, D. E. (Ed.). Nitrogenammoniaprotein modified Kjeldahl method titanium oxide + copper sulfate catalyst. Retrieved April 2, 2008, from http://www.aocs.org.

Do, T. T. H., \& Truong, T. M. T. (2013). Nutritional value of Pangasius catfish (Pangasianodon hypophthalmus) and exploiting value-added products. Can Tho, Vietnam: Can Tho University Publishing House.

Huynh, T. B. H. (2016). Study on protein hydrolysis of crocodile meat by protease enzyme (Unpublished master's thesis). Nong Lam University, Ho Chi Minh city, Vietnam.

Laemmli, U. K. (1970). Cleavage of Structural Proteins during the Assembly of the Head of Bacteriophage T4. Nature 227 (5259), 680-685.

Luan, L., \& Li-jiao, C. (2009). Two-step Enzymolysis Technology of Hard Clam (Meretrix meretrix L.) Meat with Compound Proteases. Food Science 30(9), 158162.

Nguyen, T. C. (1998). Enzyme technology. Ho Chi Minh, Vietnam: Agricultural Publishing House.

Nicharee, W., \& Sasithorn, K. (2015). Production of fish protein hydrolysates by acid and enzymatic hydrolysis. Journal of Medical and Bioengineering 4(6), 466.

Pham, C. T. T., \& Phan, N. T. (2006). Biotechnology 3. Ho Chi Minh, Vietnam: Education Publishing House.

Pham, D. D., \& Tran, L. V. (2013). Use of hydrolysate solution from enzyme-treated fish by-products for fertilizing greenhouse vegetables. Retrieved December 8, 2013, from http://cesti.gov.vn.

Ronald, E. W., Terry, E. A., Eric, A. D., Michael, H. P., David, S. R., Steven, J. S., Charles, F. S., Denise, M. S., \& Peter, S. (2005). Handbook of Food Analytical Chemistry. New Jersey, USA: John Wiley \& Sons. 